\title{
The Influences of Covert Narcissism on Displaced Aggression in Late Childhood: The Mediating Effects of Internalized Shame and Rejection Sensitivity
}

\author{
Hye Eun Lim, Sae-Young Han \\ Department of Child Development, Ewha Womans University, Seoul, Korea \\ 학령후기 아동의 내현적 자기애가 전위 공격성에 미치는 영향: \\ 내면화된 수치심과 거부민감성의 매개효과 \\ 임혜은, 한세영 \\ 이화여자대학교 아동학과
}

Objective: This study aimed to examine the mediating effects of internalized shame and rejection sensitivity in the relationship between covert narcissism and displaced aggression in late childhood.

Methods: The participants included 1,060 children (grades 5 and 6; 547 boys and 513 girls) from four elementary schools located in Seoul, Gyeonggi-do, and Chungcheong-do.

Results: The primary results of this study were as follows. First, child covert narcissism had a direct effect on displaced aggression; children who perceived higher levels of covert narcissism exhibited more displaced aggression. Second, child covert narcissism had an indirect effect on their displaced aggression through internalized shame and rejection sensitivity. Children who perceived higher levels of covert narcissism reported more internalized shame and rejection sensitivity, which led to more displaced aggression.

Conclusion: The findings of this research indicate that individual and interpersonal psychological factors need to be considered to explain displaced child aggression. Further, it is important that we help children to gain positive relationships with family and peers. It will help them break away their negative self or others representation, especially their internalized shame and rejection sensitivity.

Keywords: covert narcissism, displaced aggression, internalized shame, rejection sensitivity

\begin{abstract}
서론
불특정 다수의 무고한 사람들을 대상으로 이루어진 무동기 범

Corresponding Author: Han, Sae-Young, Department of Child Development, Ewha Womans University, 52, Ewhayeodae-gil, Seodaemungu, Seoul 03760, Korea

E-mail: evenhow@ewha.ac.kr
\end{abstract}

죄, 일명 ‘묻지마 범죄’라는 공통점을 가진 사회적 범죄가 점차 저연령화 됨에 따라 청소년 범죄에서도 이유 없이 주차된 차 량을 부수거나, 초등학생이나 여성, 노인과 같은 약자를 대상

(C)The Korean Association of Child Studies

This is an Open Access article distributed under the terms of the Creative Commons Attribution Non-Commercial License (http:// creativecommons.org/licenses/by-nc/4.0) which permits unrestricted noncommercial use, distribution, and reproduction in any medium, provided the original work is properly cited. 
으로 무참히 폭행하는 식으로 무동기 범죄의 수위가 갈수록 높아지고 있다. 이처럼 무고한 대상을 향한 공격성에 대해 사 회적 관심이 높아지면서 학계에서는 위 현상들을 설명할 수 있는 개념 중 하나인 '전위 공격성(displaced aggression)'에 대한 연구의 움직임이 일어나고 있다.

전위 공격성은 분노를 유발한 대상에게 직접적으로 분노 를 표출할 수 없는 경우 공격성을 억제하였다가 다른 무고한 대상에게 표출하는 공격성을 의미한다(Dollard, Miller, Doob, Mowrer, \& Sears, 1939). 이처럼 전혀 예측할 수 없는 상황에 서 발생되는 전위 공격성은 특히 자신보다 약하거나 친밀하 게 느끼는 대상에게 전위된 공격행동을 표출하는 경향이 있는 데(Averill, 1983), 이러한 특성은 아동-청소년과 관련해서 주 로 자신보다 약한 또래를 대상으로 삼아 행해지는 또래괴롭 힘이나 따돌림을 포함한 학교폭력과도 관련이 있다고 보았다 (Denson, 2008). 과거에는 주로 중·고등학생 위주로 발생했던 학교폭력이 이제는 초등학교 때부터 경험하는 것으로 나타나 또래괴롭힘을 포함해 학교폭력의 발생시기가 점차 저연령화 되고 있으며(Jo, 2013), 그 방법 또한 점점 잔인하고 비인간적 인 방법으로 이루어지는 특징을 보인다. 가해자들의 가해 이 유를 살펴보면 '재미있어서', '이유 없음' 등 뚜렷한 동기가 나 타나지 않으며, 피해자에 대한 죄의식이나 미안함을 보이지 않는 심각성을 지닌다(S. G. Kim, 2005). 이런 점들을 미루어 볼 때, 최근 발생되고 있는 또래괴롭힘이나 학교폭력은 단지 예전처럼 분노유발자에 대한 직접적인 공격의 일환으로 치부 하기보다는 오히려 자신보다 약하고 무고한 또래들을 대상으 로 자행되어지는 전위 공격성의 한 형태로 보고 접근하는 것 이 더 타당해 보인다.

이처럼 학령후기는 발달적으로 청소년기로 전이되는 이 른 사춘기를 겪는 시기로 초등학교 때 시작된 또래괴롭힘이 나 공격성 패턴이 청소년기 전반에 걸쳐 유지되기가 쉬우며 (H. Kim \& Lee, 2000), 청소년기와 성인기 이후까지도 폭력 의 가능성을 예측하는 요인이 됨에 따라 사회부적응 및 반 사회적인 문제로까지 이어지는 특성을 보인다(Farrington, 2005; McCord, 1988; Nagin \& Tremblay, 1999; Olweus, 1991; Tremblay, 2000; Walker, Severson, Feli, Stiler, \& Golly, 1998), 따 라서 학령기는 추후 발생될 부적응적인 문제행동을 조기개입 만으로도 예방할 수 있는 매우 중요한 시기인 만큼 학령후기 아동의 전위 공격성에 관한 집중적인 연구와 개입의 필요성이 절실히 요구된다.

전위 공격성은 유발된 분노를 억제하였다가 무고한 상대에 게 표출되는 형태로 공격성을 보이는 만큼 이는 개인의 위축
된 자아성향과 연관성이 있으며, 또한 타인과의 관계를 의식 하는 내적성향과도 관계가 있을 것으로 추론됨에 따라 전위 공격성과 다양한 내적심리요인들과의 관련성을 예측할 수 있 다. 이에 본 연구에서는 전위 공격성의 첫 번째 선행요인으로 생애초기단계에 가장 먼저 형성되는 자아상의 일환 중 하나인 내현적 자기애(covert narcissism)와의 관계를 살펴보고자 한다. 먼저 Bowlby (1973)의 애착이론에 따르면, 자기애(narcissism) 는 생애초기 주 양육자와의 상호작용에 의해 형성된 애착의 결과로 이 시기에 부적절한 양육을 받아 불안정애착을 형성한 경우 부정적인 자기표상이 내재됨에 따라 이는 병리적인 자기 애로 발전한다고 보았다(van der Waals, 1965). 병리적 자기애 중에서도 '내현적 자기애'가 높은 사람은 자기상이 상처를 입 는 것에 예민하고 타인의 반응에 매우 민감하여 타인의 비난 과 비판에 대한 두려움을 피하는 방식으로 취약한 자기를 보 호하고자 하는 특성을 가지며(Cooper, 1998; Gang \& Chung, 2002), 타인으로부터 비난받을 것을 우려하여 즉각적인 공격 성을 드러내기보다는 오히려 다른 대상에게 전위된 공격성을 드러내는 경향을 보인다(Loudin, Loukas, \& Robinson, 2003). Freud의 추동감소이론(drive-reduction theory) 역시 개인이 좌 절을 겪은 경우, 이 때 경험한 좌절감과 박탈감이 분노를 일으 켜 공격적인 행동으로 이어지게 되는데(Dollard et al., 1939), 특히 자기애가 높을수록 좌절 상황에서 좌절감을 유발시킨 당 사자가 아닌 전혀 관계없는 대상에게 공격행동을 보인다고 하 였다(Twenge \& Campbell, 2003). 최근 내현적 자기애와 전위 공격성의 관계를 살펴본 연구에서도 내현적 자기애는 전위 공 격성에 유의미한 영향을 미치는 것으로 나타나(Cho \& Kwak, 2012) 내현적 자기애는 전위 공격성을 예측하는 중요한 요인 임을 밝혔다.

부정적인 자기애를 지닌 사람은 자기 또는 타인과의 관계 를 바라보는 시각이 부적절하거나 부적응적인 경향성을 보 이는데, 부적절한 자기애는 개인 및 타인과의 관계에 대한 인식을 왜곡시킴으로써 타인을 향해 공격적인 반응을 표출 할 수 있는 가능성을 보여준다(Gwak \& Ha, 2010; K.-J. Lee, Hwang, \& Jeong, 2015; Oh \& Park, 2012). 따라서 자신을 바라 보는 시각이자 전반적인 자기(self) 평가인 '내면화된 수치심 (internalized shame)'과 자신과 타인과의 관계에 대한 정서적 시 각인 '거부민감성(rejection sensitivity)', 이 두 가지 내적심리요 인이 내현적 자기애와 전위 공격성의 관계에서 어떠한 매개적 역할을 하는지 함께 고려하여 살펴보고자 한다.

내면화된 수치심은 수치심이 내면화되어 개인이 자기(self) 에 대해 만성적으로 부적절하고 무가치하다고 느끼는 부정적 
인 자의식 정서로서 자기에 대한 부정적 표상인 내적작동모델 (internal working model)로부터 기인한 만큼 대인관계에서 부 적절한 행동방식을 동기화시키는 주요한 변인으로 주목받고 있다(Nam, 2002). 이는 주로 아동기에 사랑 철회의 경험이 있 거나(H. B. Lewis, 1987) 양육자로부터 부정적인 양육을 경험 하였을 때 수치심이 발달하게 되며(Tangney \& Dearing, 2002), 특히 내현적 자기애가 높은 경우에는 자기애적 좌절에 취약함 을 보임에 따라(Kernberg, 1975; Kohut, 1971; Morrison, 1983) 자기 존재에 대한 내면화된 수치심을 형성하게 된다(Allan, Gilbert, \& Goss, 1994; Kaufman, 1989; H. B. Lewis, 1971). 이처 럼 내현적 자기애가 높을수록 수치심이나 굴욕감을 쉽게 느낀 다고 보고된 것과 같이 두 변인 간에는 밀접한 관련성을 보인 다(Akhtar \& Thompson, 1982; Gwak \& Ha, 2010; M.-S. Kang \& Lee, 2011; Kohut, 1977; I. S. Lee \& Choi, 2005).

한편, 수치심은 공격성의 하위개념인 분노나 적대감과 도 정적인 관계를 보이고 있으며(Tangney, Wagner, Fletcher, \& Gramzow, 1992; Tangney, Wagner, Hill-Barlow, Marschall, \& Gramzow, 1996), 수치심이 높을수록 공격성을 포함한 전위 공격성 역시 높게 나타났다(An \& Lee, 2013; Han, 2007; J. Y. Hwang, 2014; P. H. Kim \& Yun, 2014). 수치심이 높을수록 전 반적으로 자신에 대해 부정적 정서를 가지게 되며, 내현적 자 기애와 마찬가지로 타인의 시선을 의식하는 경향이 있어 타인 으로부터 비난이나 비판받는 것을 두려워하고, 이에 분노나 적대감을 직접적으로 표출하기보다는 오히려 억제하는 방식 으로 전위된 공격성을 더 많이 드러낸다(Tangney et al., 1992). 내면화된 수치심이 높은 아동 또한 전위 공격성의 주요 특성 인 반추 성향을 보임에 따라(Joireman, 2004) 오히려 전위된 공 격성의 형태로 나타날 가능성이 높다.

이와 더불어 거부민감성은 자신 뿐 아니라 자신과 타인의 관계를 바라보는 관점에 초점을 둔 인지적인 정서 상태로, 타 인과의 관계에서 거부될 것을 예상하는 경우 예기불안이나 예기분노를 느끼고 민감하게 반응한다(Feldman \& Downey, 1994). 거부민감성이 높을수록 상대방의 모호한 행동에도 고 의적인 거절로 지각하고 예민하게 반응하는 경향을 보이는 만 큼 타인에 대한 부정적인 표상을 반영하고 있다. 거부민감성 은 자신 뿐 아니라 타인의 관계에 대한 상대적 반응이라는 점 에서 자기애나 수치심과 구별되지만, Bowlby의 내적작동모델 에 따라 발달된 심리적 기제라는 점에서 자기애와도 연관성 을 보인다(M.-S. Kim, 2014; K.-J. Lee et al., 2015). 이에 수치심 또한 자기에 대한 부정적인 평가인 만큼 대인관계에서도 타 인에 의해 부정적으로 평가되는 것에 예민함을 보여(Harder,
$1990)$ 거부민감성의 예측요인으로 작용한다(J.-Y. Hong \& Han, 2015; J. Hwang \& Ahn, 2015). 다시 말해, 수치심이 높을 수록 스스로 적대감을 가지며, 이로 인해 다른 사람으로부터 자신이 거부될 것을 기대하게 됨에 따라(M. Lewis, Alessandri, \& Sullivan, 1992) 이러한 유기에 대한 두려움은 거부 상황에 대해 더욱 민감해지게 만든다(Piers \& Singer, 1953). 이와 같이 거부민감성을 예민하게 지각할수록 대인관계에서도 타인의 모호한 자극을 거부단서로 파악하여 적대적 행동 및 공격적인 반응이 나타나게 된다(Ayduk, Gyurak, Luerssen, 2008; Dodge, 1980; S.-H. Hong \& Lee, 2013; W. R. Park \& Hong, 2015). 아직 까지 거부민감성과 전위 공격성과의 관계를 직접적으로 살펴 본 연구는 부족한 상황이나 거부민감성은 전위 공격성의 주요 특성인 분노억제(S.-H. Hong, 2012) 및 반추(E.-Y. Kang \& Lee, 2014)와도 정적인 상관을 보임에 따라 전위 공격성을 예측하 는 중요한 선행요인으로 예측해볼 수 있다.

위의 내용들을 정리해보면, 자기에 대한 부정적인 자아상 인 내현적 자기애가 높을수록 자기 존재에 대한 부적절한 자 의식 정서인 내면화된 수치심을 자주 경험하게 되고, 부정적 인 평가를 받는 것을 두려워하여 타인의 시선을 의식하는 경 향을 보인다. 또한, 내면화된 수치심은 부정적인 자기표상에 서 비롯된 부적절한 자기평가인 만큼 타인 역시도 자신을 부 적절하게 바라볼 것으로 인식을 왜곡시킴으로써 대인관계에 서도 거부될 것으로 예상함에 따라 이는 거부민감성을 더욱 증가시키게 된다. 이로 인해 더욱 높아진 타인에 대한 경계심 과 예민함으로 타인으로부터 비난받을 상황을 우려하게 되어 자신의 분노를 즉각적으로 분출하기 보다는 오히려 억제하고 통제하였다가 이와 관련이 없는 약한 상대에게 전위 공격성을 표출하게 된다는 것을 추론해볼 수 있다. 따라서 본 연구에서 는 네 변인들 간의 관계를 동시에 살펴보고자 하였다.

국내에서 이루어진 공격성에 관한 연구들은 주로 직접적인 공격성에만 초점이 맞춰져 있으며(Doh, Choi, \& Lee, 2005; J. $\mathrm{Kim}, 2009 ; \mathrm{H}$. Lee \& Kim, 2012), 전위 공격성에 관한 연구는 거의 초기 탐색적 단계에 이른다. 게다가 지금까지는 전위 공 격성이 청소년 및 성인의 발달적 결과에 미치는 영향을 주로 강조해온 반면(S. J. Hwang \& Park, 2014; H. N. Lee, 2009; K. H. Park \& Seo, 2013), 전위 공격성을 유발시키는 선행요인들 에 관한 연구는 비교적 드문 편이다. 이에 본 연구는 전위 공격 성과 이를 예측하는 개인 심리 및 관계적 기제에 관한 연구가 아직은 많이 부족하다는 점에 관심을 가지고 학령후기 아동의 내현적 자기애가 전위 공격성에 미치는 직접적인 관계와 내면 화된 수치심과 거부민감성을 매개로 하여 전위 공격성에 미치 
는 간접적인 경로를 탐색해보고자 하였다. 또한, 개인 및 대인 간 내적심리기제를 통해 접근함으로써 전위 공격성의 발달과 정을 보다 심층적으로 이해하여 전위 공격성과 관련된 부적응 적인 문제행동을 예방하고, 구체적인 해결방안을 모색하는데 유용하게 활용될 수 있을 것으로 기대한다.

\section{연구문제 1}

학령후기 아동의 내현적 자기애는 전위 공격성에 직접적인 영향을 미치는가?

\section{연구문제 2}

학령후기 아동의 내현적 자기애는 내면화된 수치심과 거부민 감성을 매개하여 전위 공격성에 간접적인 영향을 미치는가?

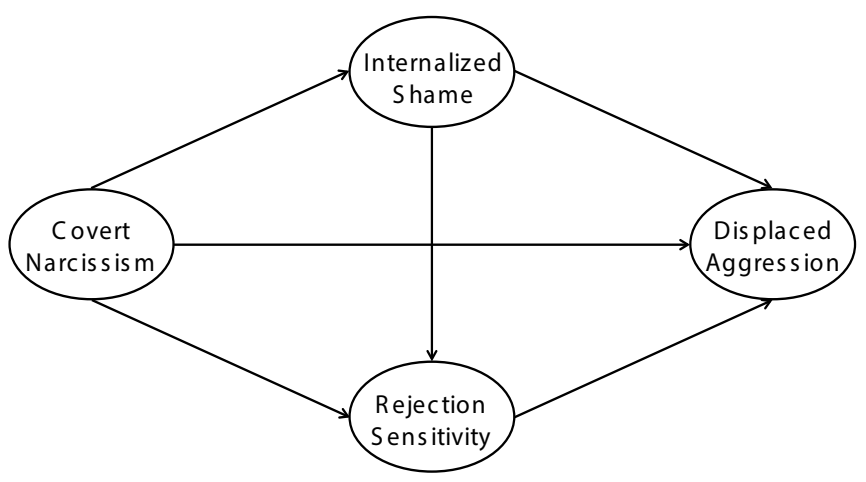

Figure 1. Diagram of paths from covert narcissism to displaced aggression through internalized shame and rejection sensitivity.

\section{연구방법}

\section{연구대상}

본 연구는 서울, 경기도 및 충청도 소재의 4 개 초등학교에 재 학 중인 5, 6학년 남.여 학생 1,060명(남학생 547명, 여학생 513 명)을 대상으로 질문지법을 이용한 자기보고방식을 통해 자료를 수집하였다. 연구대상으로 초등학교 5, 6학년을 선정 한 이유는 학령후기에 속하는 초등학교 5, 6학년은 발달적으 로 청소년기로 전이되는 이른 사춘기를 겪는 시기로 최근 전 위 공격성의 한 형태인 또래괴롭힘을 포함한 학교폭력의 발생 시기가 점차 저연령화 되고 있으며, 초등학교 때 시작된 또래 괴롭힘이나 공격성 패턴은 청소년기 전반에 걸쳐 유지되기가 쉬워(H. Kim \& Lee, 2000) 학교폭력이나 청소년 비행, 더 나아
가서는 성인범죄 등 반사회적인 문제로까지 이어지는 특성을 가진다(McCord, 1988; Olweus, 1991; Tremblay, 2000; Walker et al., 1998). 또한, 학령기에 이르기까지 가정 내 양육환경 및 교 내 또래 및 교사와의 관계 속에서 형성되어진 개인 및 대인간 심리적 요인에 의해 공격성을 포함한 다양한 부적응적인 문 제행동들을 시도함에 따라 이는 조기개입을 통해 예방할 수 있는 매우 중요한 시기라고 볼 수 있다. 이는 학령후기 아동의 공격성은 현재 뿐 아니라 미래의 사회부적응과 반사회적 행 동을 예측하는 강력한 행동지표로 작용함에 따라 $(\mathrm{Ha} \& \mathrm{Kim}$, 2012) 청소년기 진입을 앞둔 학령후기 아동의 전위 공격성에 대한 집중적인 연구와 개입의 필요성이 절실히 요구되는 시 기라고 판단하여 연구대상으로 선정하였다. 본 연구대상자 의 인구통계학적 특성을 살펴보면, 아동의 성별은 남학생 547 명(51.6\%), 여학생 513명(48.4\%)이었으며, 학년 구성은 5학년 456명(43.0\%), 6학년 604명(57.0\%)로 6학년이 다소 높은 비율 을 차지하였다.

\section{연구도구}

본 연구의 조사도구는 전위 공격성, 내현적 자기애, 내면화된 수치심, 거부민감성을 측정하기 위한 네 개의 척도로 구성되 었으며, 아동의 자기보고식 질문지 방식으로 측정하였다. 또 한, 중간값에 응답하는 중심화오류를 방지하고자 모든 척도를 4점 Likert 척도 (1: 전혀 그렇지 않다 4: 매우 그렇다)로 변 환하였다.

\section{전위 공격성}

Denson, Pedersen과 Miller (2006)가 개발한 전위 공격성 척도 (Displaced Aggression Questionnaire [DAQ])는 총 31문항으로, 7점 Likert 척도의 자기보고식 질문지로 되어있다. 전위 공격 성 척도는 감정적 요소인 분노반추(anger rumination), 인지적 요소인 보복계획(revenge planning), 행동적 요소인 전위된 공 격행동(behavioral displaced aggression)으로 세 가지 하위요인으 로 구성되어 있다. 본 연구에서는 H. N. Lee (2009)가 한국판으 로 번안하고 타당화한 척도를 사용하였으며, 총 27문항으로 이루어져 있으며, 원 척도에서의 7점 Likert 평정 척도를 4점 Likert 척도(1: 전혀 그렇지 않다 4: 매우 그렇다)로 변환하 였다. 각 하위요인별 문항들을 살펴보면, 분노반추( 10 문항)의 경우, "나는 나를 화나게 만든 일에 대해서 오랫동안 지속적으 로 생각한다.", 보복계획(8문항)의 경우, "누군가가 내 기분을 
건드리면 언제고 반드시 보복(복수)한다.”, 전위된 공격행동(9 문항)의 경우, "나는 기분이 나쁘면 다른 사람에게 화풀이 한 다." 등의 문항으로 이루어져 있다. 본 연구에서의 내적합치도 (Cronbach's $\alpha$ )는 분노반추 .93, 보복계획 .92, 전위된 공격행동 .91 이었다.

\section{내현적 자기애}

내현적 자기애를 측정하기 위하여 S.-H. Hong, Gwak과 Han (2010)이 아동.청소년 및 성인의 자기애를 다룬 선행연구들과 자기애 척도들의 문항을 참고하여 자기애에서 일반적으로 나 타나는 증상이나 핵심 특징을 도출하여 초등학교 4-6학년을 대상으로 재구성한 아동용 자기애 척도를 사용하였다. S.-H. Hong 등(2010)의 자기애 척도는 외현적 자기애와 내현적 자 기애 두 가지로 구성되어 있다. 외현적 자기애는 3 개의 하위요 인(우월의식, 리더십, 칭찬과 자기인정 욕구) 24 문항을 포함하 고 있으며, 내현적 자기애는 3 개의 하위요인(착취와 공격성, 과민성과 취약성, 자기중심성) 18 문항으로 구성되어 있음에 따라 점수가 높을수록 자기애 성향이 높음을 의미한다. 본 연 구에서는 내현적 자기애(Covert Narcissism Scale [CNS])를 측 정하는 18 문항만을 발췌하여 사용하였으며, 착취와 공격성 $(5$ 문항)의 경우, "다른 아이들이 나를 무시하면 똑같이 해준다." 등이 포함되고, 과민성과 취약성(6문항)의 경우, "다른 사람들 이 내게 하는 말이 욕처럼 들릴 때가 자주 있다.” 등이 있으며, 자기중심성(7문항)의 경우에는 "나와 다르게 생각하는 사람 을 보면 이해할 수 없다.” 등의 문항이 포함되어 있다. 본 연구 에서의 내적합치도(Cronbach's $\alpha$ )는 착취와 공격성 .69, 과민성 과 취약성 .79, 자기중심성 .76이었다.

\section{내면화된 수치심}

Cook (1994)이 1987년에 개발한 내면화된 수치심 척도 (Internalized Shame Scale [ISS])는 총 30문항으로, 5점 Likert 척 도의 자기보고식 질문지로 되어있다. 이 척도는 수치심을 측 정하는 24 문항과 6 개의 자존감 문항으로 구성되어 있으며, 자 존감 문항은 문항이 같은 방법으로 주어져 있을 경우 한 방향 으로 응답하려는 경향을 제어하기 위해 Rosenberg 자존감 척 도에서 6문항을 가져와 ISS에 포함시킨 것이다. 본 연구에서 는 I. S. Lee와 Choi (2005)가 번안하고 타당화한 척도를 사용 하였으며, 허수문항인 자존감 6 문항을 제외한 수치심을 측정 하는 24 문항만을 발췌하여 사용하였는데, 원 척도에서의 5 점
Likert 평정 척도를 4점 Likert 척도(1: 전혀 그렇지 않다 4: 매우 그렇다)로 변환하였다. 각 하위요인별 문항들을 살펴보 면, 부적절감(10문항)의 경우, "나는 내 자신이 매우 작고 보잘 것 없이 느껴진다.", 공허(5문항)의 경우, "나는 마음이 텅 빈 것(공허함)처럼 채워지지 않음을 느낀다.”, 자기처벌(5문항)의 경우, "때로는 내가 산산조각이 나서 부서질 것 같이 느껴진 다.”, 실수불안(4문항)의 경우, "실수를 하면 나는 움츠려 드는 것만 같다.” 등의 문항이 포함되어 있다. 이 중 아동이 이해하 기 어려운 어휘가 사용된 문항은 용어의 의미를 풀어 설명함 으로써 부분적으로 보완하였는데, 예를 들어 원 문항에서 "나 는 공허하고 채워지지 않음을 느낀다."를 "나는 마음이 텅 빈 것(공허함)처럼 채워지지 않음을 느낀다."로 부분 수정하였 으며, "나의 외로움은 텅 빈 공허감과 같다."는 원 문항은 "나 는 때론 무언가 텅 빈 것 같은 외로움을 느낀다.”로 수정.보완 하였다. 본 연구에서의 내적합치도(Cronbach's $\alpha$ )는 부적절감 .90 , 공허 .87 , 자기처벌 .81 , 실수불안 .79 이었다.

\section{거부민감성}

아동의 거부민감성을 측정하기 위해 Downey와 Feldman (1996) 이 개발한 아동용 거부민감성 질문지(Children's Rejection Sensitivity Questionnaire [CRSQ])를 K. S. Lee, Seo와 Shin (2000) 이 번안한 것을 바탕으로 J.-Y. Park과 Chong (2008)이 보완한 한국판 아동용 거부민감성 척도(The Korean Children's Rejection Sensitivity Questionnair [K-CRSQ])를 사용하였다. K-CRSQ는 또래 관련 상황 8 가지, 교사관련 상황 4 가지로 총 12 가지 거부 상황에서 아동이 거부를 예상할 때 경험하는 불안, 분노, 우울 이라는 3 가지 예기정서와 해당 상황에서 거부가 예상되는 정 도(거부예상신념)를 5점 Likert 척도(1: 전혀 그렇지 않다 5: 매우 그렇다)로 평정하도록 되어 있으나, 본 연구에서는 거부 예기정도를 제외한 거부불안, 거부분노, 거부우울의 36 문항 을 사용하였으며, 4점 Likert 척도(1: 전혀 그렇지 않다 4: 매 우 그렇다)로 측정하였다. 각 하위요인별 문항들을 살펴보면, 거부불안(12문항)의 경우, "친구가 먼저 가 버렸을까봐 걱정 이 되거나 불안한가요?”, 거부분노(12문항)의 경우 “선생님께 서 나를 내 이야기를 듣고 계시지 않을까봐 짜증이 나거나 화 가 나나요?", 거부우울(12문항)의 경우, “친구가 내게 초대장 을 주지 않을까봐 속상하거나 우울한가요?” 등의 문항으로 이 루어져 있다. 본 연구에서의 내적합치도(Cronbach's $\alpha$ )는 거부 불안 .94, 거부분노 .92, 거부우울 .93 이었다. 


\section{연구절차}

본 조사는 2015년 6-7월 중에 서울, 경기도 및 충청도 소재의 4 개 초등학교 5, 6학년 남.여 학생 1,077명을 대상으로 설문조 사를 실시하였다. 설문을 실시하기에 앞서 아동의 이해도를 확인하기 위해 5,6 학년 각 2 명씩 총 4 명에게 예비조사를 실시 하였다.

자료 수집은 본 연구자가 사전에 학교 측에 협조를 구한 뒤 학교사정에 따라 수업시간 전후로 담임교사의 주도 하에 설문 지를 나누어 준 다음, 학생들이 스스로 기입하여 회수하는 집 단조사 방법을 사용하였다. 전체 1,125 부를 배부하여 1,077 부 를 회수하였으며, 이 중 설문 내용의 $10 \%$ 이상을 무응답으로 처리한 경우와 전체 문항을 한 번호에 일렬로 체크하는 등 무 성의하게 응답한 17 부의 자료를 제외하고 최종적으로 1,060 명의 자료를 분석하였다.

\section{자료분석}

수집된 자료는 SPSS 21.0 (IBM Co., Armonk, NY)과 AMOS 22.0 (IBM Co., Armonk, NY) 프로그램을 사용하여 분석하였
다. 먼저 연구대상자의 인구통계학적 배경을 살펴보기 위해 SPSS 21.0을 이용하여 빈도분석과 기술통계분석을 실시하였 으며, 조사도구의 신뢰도를 검증하기 위해 Cronbach's $\alpha$ 계수 에 의한 내적합치도를 산출하였고, 전체 연구변인들 간의 상 관관계를 살펴보기 위해 Pearson의 적률상관계수를 산출하였 다. 다음으로 가설검증을 하기 위해 AMOS 22.0을 이용하여 구조방정식 모형(Structural Equation Modeling [SEM])을 이용 한 매개모형 검증을 실시하였다. 먼저 모형의 적합도를 검증 한 후, 연구변인 간 경로를 탐색하였으며, 연구변인들 간의 경 로에 있어서 직.간접효과를 확인하는 과정에서 매개변인의 간접효과 유의도는 부트스트래핑(bootstrapping) 기법을 사용 하여 검증하였다.

\section{연구결과}

\section{측정변인들 간 상관관계}

학령후기 아동의 내현적 자기애, 전위 공격성, 수치심, 그리고 거부민감성 간의 경로를 구조방정식 모형으로 분석하기에 앞

Table 1

Correlations Among Covert Narcissism, Internalized Shame, Rejection Sensitivity, and Displaced Aggression

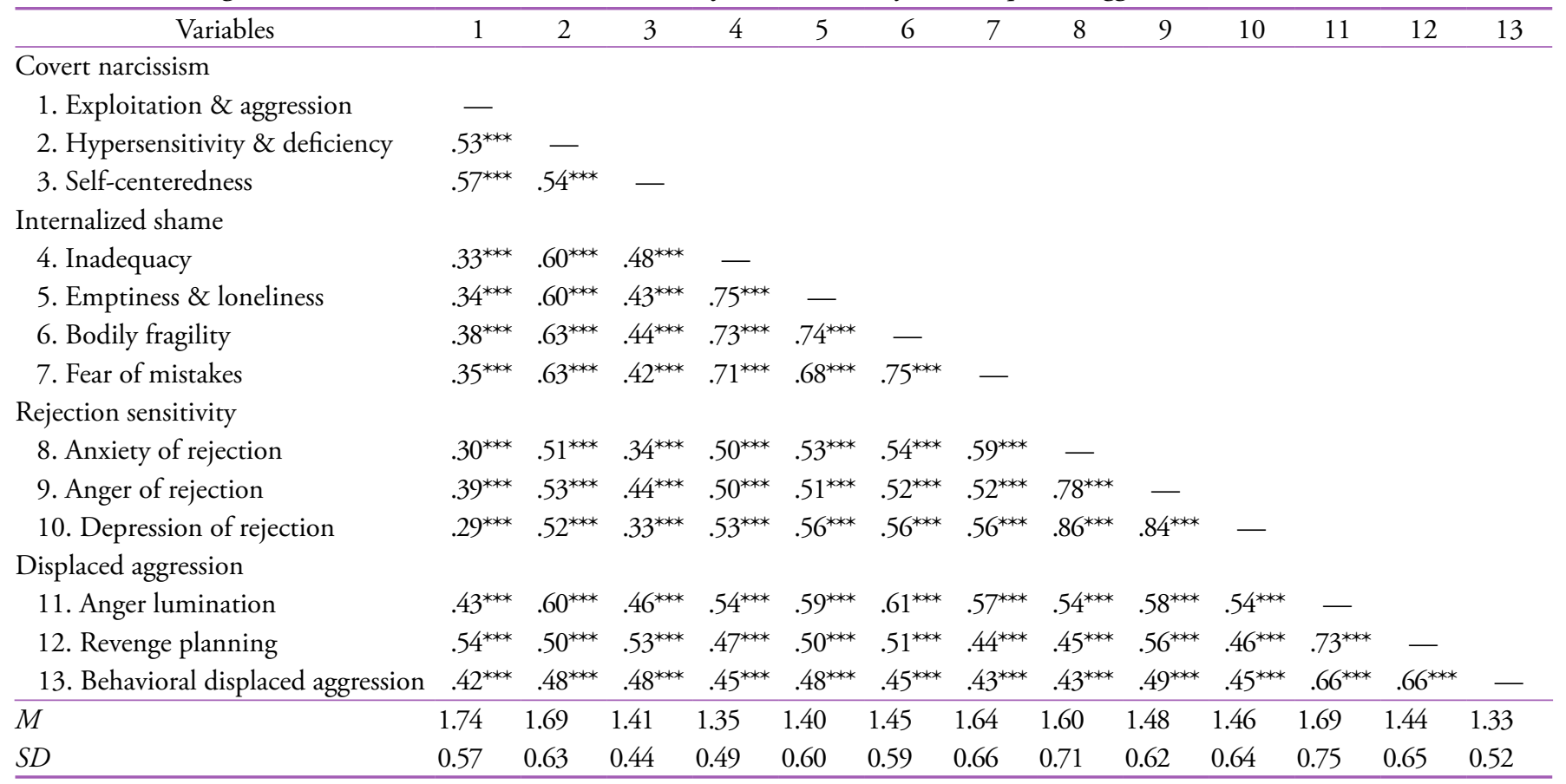

Note. $N=1,060$.

${ }^{* * *} p<.001$. 
서, Pearson의 적률상관계수를 산출하여 측정변인들 간의 상관 관계를 살펴보았다. 그 결과, 모든 측정변인들 간에는 유의한 정적상관을 갖는 것으로 나타났다(Table 1). 첫째, 내현적 자기 애는 내면화된 수치심 $(r=.60-.63, p<.001)$, 거부민감성 $(r=$ $.51-.53, p<.001)$, 그리고 전위 공격성 $(r=.42-.60, p<.001)$ 의 모든 하위요인들과 정적상관을 보였다. 즉, 내현적 자기애 가 높을수록 자신에 대한 부적절감이나 자기처벌 등의 내면화 된 수치심을 더 많이 경험하고, 거부단서에 대해 매우 민감하 며, 높은 전위 공격성을 보였다. 둘째, 내면화된 수치심은 거 부민감성 $(r=.50-.59, p<.001)$ 과 전위 공격성 $(r=.43-.61, p$ <.001)의 모든 하위요인들과 정적 상관을 보였다. 즉, 내면화 된 수치심이 높을수록 거부단서에 예민하며, 분노를 반추하거 나 전위된 공격행동 등을 표출하는 경향이 높은 것으로 나타 났다. 셋째, 거부민감성은 전위 공격성 $(r=.43-.58, p<.001)$ 의 모든 하위요인들과 정적 상관을 보였다. 즉, 거부민감성이 높을수록 높은 분노를 유발시킨 대상이 아닌 무고한 타인에게 전위된 공격성을 드러내는 경향이 높게 나타났다.

\section{측정모형 분석}

연구모형의 구조적 관계를 검증하기에 앞서, 학령후기 아동의 내현적 자기애, 내면화된 수치심, 거부민감성, 전위 공격성을 설명하는 측정변인들의 타당성을 확인하기 위해 확인적 요인 분석을 실시하였다.

적합도 지수에 관한 기준과 관련하여 $\mathrm{Hu}$ 와 Bentler (1999) 는 Monte Carlo는 NFI, TLI, CFI의 경우에는 .95에 가깝거나 높아야 하며, RMSEA는 .06에 가깝거나 낮아야 한다는 보다 엄격한 적합도 기준을 제시하였다. 그러나 Steiger (1989)는 RMSEA는 .05보다 낮은 경우 매우 좋은 적합도이나 .10보다 낮은 경우 또한 양호한 적합도로 볼 수 있다고 제시함에 따라 본 연구에서는 Hu와 Bentler (1999) 그리고 Steiger (1989)의 기 준을 함께 적용하여 모형의 적합도를 평가하였다. 측정모형 을 살펴본 결과, 측정모형의 적합도는 $\chi^{2}=599.875(d f=59, p$
$<.001), \mathrm{NFI}=.944, \mathrm{TLI}=.933, \mathrm{CFI}=.949, \mathrm{RMSEA}=.093$ 으로 나타났다(Table 2). 또한, 모든 표준화된 회귀계수( $\beta$ )의 절대값 이 .65-.95로 .60이상의 요인부하량을 보였고, $\alpha=.001$ 수준 에서 모두 유의한 것으로 나타났다. 따라서 앞서 제시한 모형 적합도의 양호한 수용기준을 충족시킴으로써 모든 측정변인 들이 잠재변인의 개념을 적합하게 잘 설명해주고 있는 것으로 확인되었다(Table 2, Figure 2)

\section{구조모형 분석}

아동의 내현적 자기애가 전위 공격성에 미치는 영향을 내면화

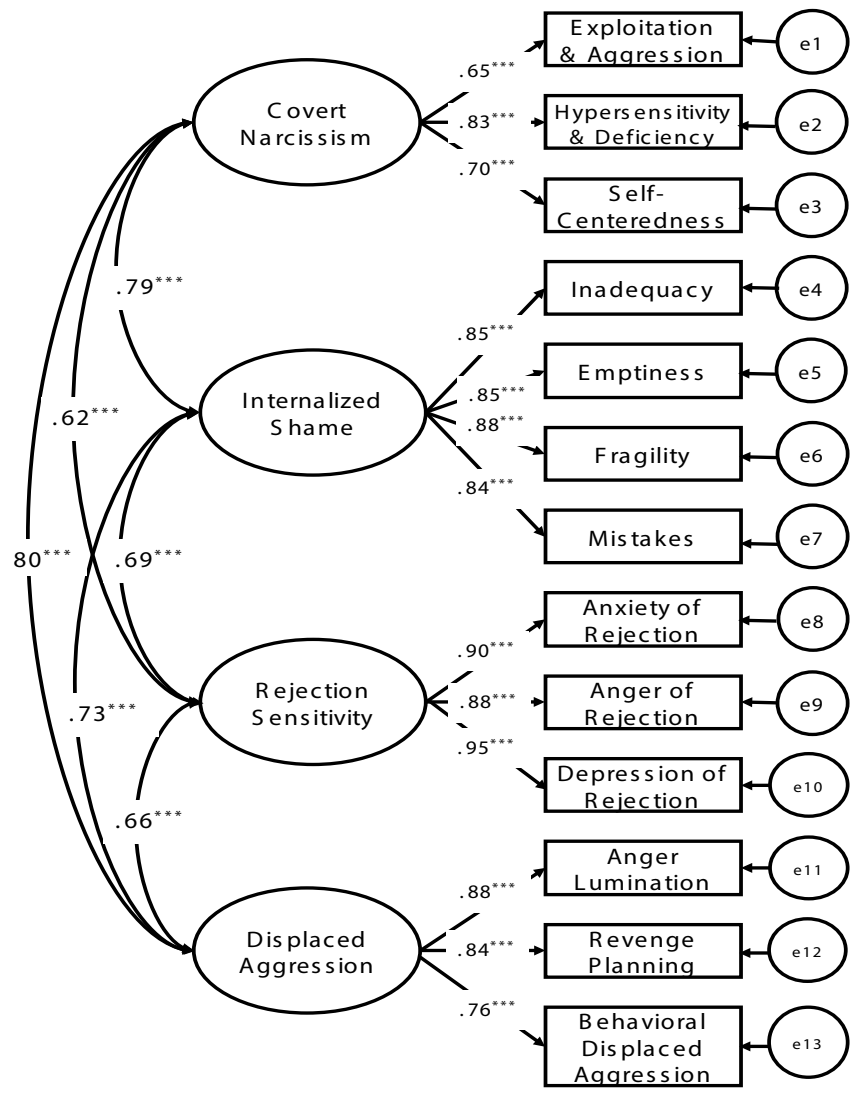

Figure 2. Factor loadings of the measurement model. ${ }^{* * *} p<.001$.

Table 2

Testing the Fit of the Measurement Model

\begin{tabular}{ccccccc}
\hline & & & & & \multicolumn{2}{c}{ RMSEA } \\
Model & $\chi^{2}$ & $d f$ & NFI & TLI & CFI & (Lo90- Hi90) \\
\hline Measurement model & $599.875^{* * *}$ & 59 & .944 & .933 & .949 & .093 \\
& & & & & $(.086-.100)$ \\
\hline
\end{tabular}

Note. $N=1,060$.

${ }^{* * *} p<.001$. 
된 수치심과 거부민감성이 이중 매개하는 연구모형을 설정하 여 구조모형 방정식을 이용해 경로분석을 통한 구조모형 분석 을 실시하였다. 그 결과, $\chi^{2}=599.875(d f=59, p<.001), \mathrm{NFI}=$ $.944, \mathrm{TLI}=.933, \mathrm{CFI}=.949, \mathrm{RMSEA}=.093$ 으로 나타나 양호 한 수준의 모형 적합도가 확인되었다. 다음의 Table 3와 Figure 3 에 제시된 구조모형 경로계수와 검증결과에서 모든 잠재변 인들 간의 경로계수가 유의한 것으로 나타났다. 이를 구체적 으로 살펴보면, 내현적 자기애에서 내면화된 수치심( $\beta=.79, p$ $<.001)$, 거부민감성 $(\beta=.21, p<.001)$, 전위 공격성 $(\beta=.57, p<$ $.001)$, 내면화된 수치심에서 거부민감성 $(\beta=.52, p<.001)$, 전
위 공격성 $(\beta=.13, p<.05)$, 거부민감성에서 전위 공격성 $(\beta=$ $.21, p<.001)$ 으로 향하는 모든 직접 경로는 유의한 영향을 미 쳤다. 중요한 것은 부정적인 자기애가 높을수록 전위된 공격 성으로 연결되는데 있어 자신에 대해 내면화된 수치심을 가장 높게 지각하는 것으로 나타났다. 또한, 내면화된 수치심이 높 게 지각될수록 거부단서에 대한 민감도 역시 증가하였으며, 이러한 내적심리기제를 통해 전위 공격성으로 연결되는 것으 로 나타났다.

다음으로 연구모형 내 변인들 간의 직접경로가 모두 유의 한 것으로 나타남에 따라 이번에는 각 변인들 간의 직·간접

Table 3

Standardized and Unstandardized Loadings of the Mediational Model

\begin{tabular}{|c|c|c|c|c|}
\hline Path loadings & $B$ & $\beta$ & $S E$ & C.R. \\
\hline \multicolumn{5}{|l|}{ Covert narcissism } \\
\hline$\rightarrow$ Internalized shame & 1.47 & $.79^{* * *}$ & .08 & 18.65 \\
\hline$\rightarrow$ Displaced aggression & .95 & $.57^{* * *}$ & .10 & 9.89 \\
\hline \multicolumn{5}{|l|}{ Internalized hame } \\
\hline \multicolumn{5}{|l|}{ Rejection ensitivity } \\
\hline$\rightarrow$ Displaced aggression & .21 & $.21^{* * *}$ & .04 & 6.07 \\
\hline
\end{tabular}

Note. $N=1,060$.

${ }^{*} p<.05 .{ }^{* * *} p<.001$.

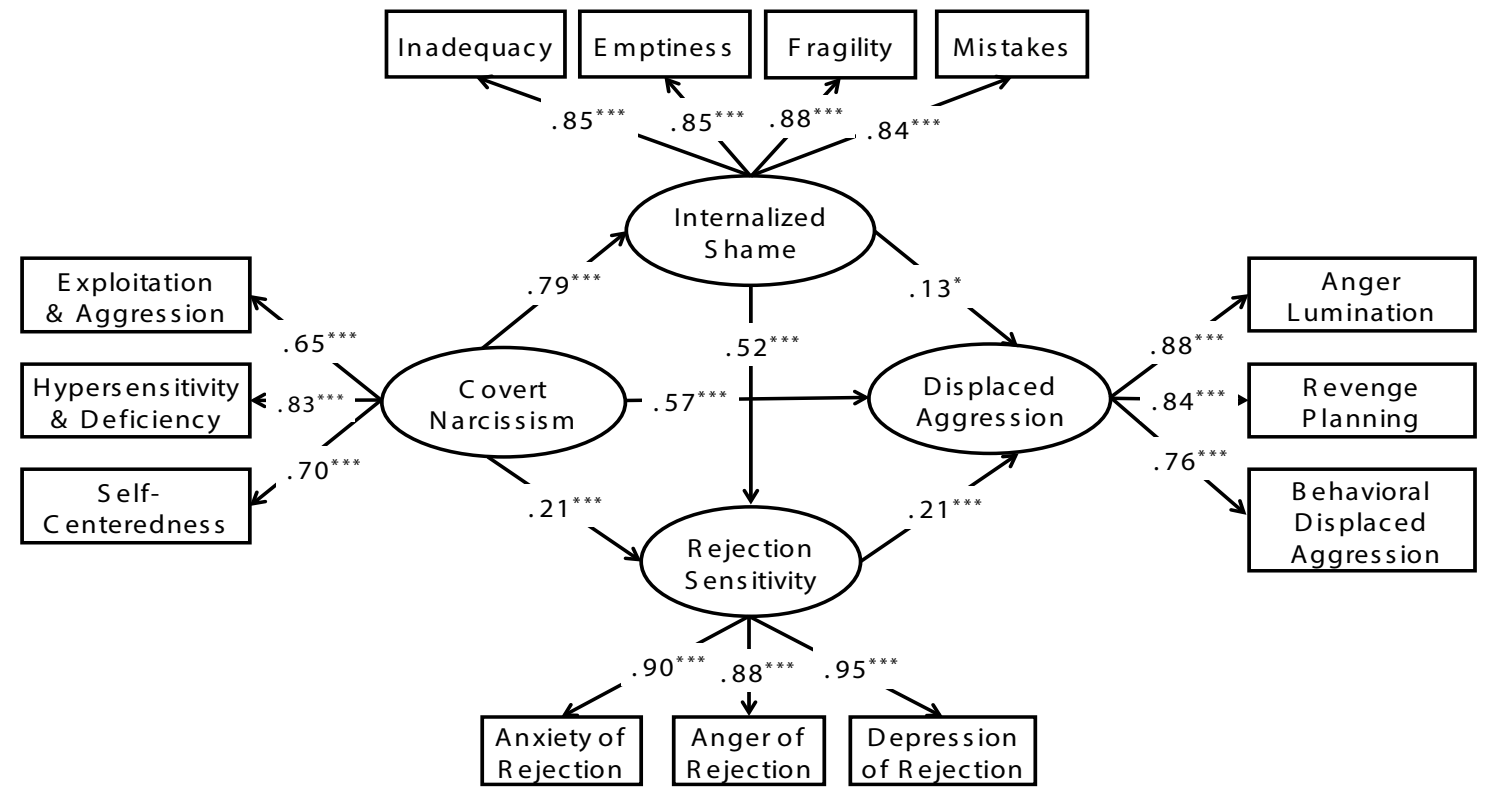

Figure 3. Diagram of direct and indirect paths from covert narcissism to displaced aggression.

${ }^{*} p<.05 .{ }^{* * *} p<.001$. 
효과와 총효과를 살펴보았다(Table 4). 구조모형 내 잠재변 인들 간의 구조적 관계를 자세히 파악하고, 전체 경로에 대 한 간접효과 뿐 아니라 개별간접효과를 확인하기 위해 팬텀 변수(phantom variable)를 설정한 후(Cheung, 2007; Rindskopf, 1984), 각 간접경로를 대상으로 부트스트래핑(bootstrapping) 기법을 적용하였다. 분석 결과, 내현적 자기애가 거부민감성 $(\beta=.41, p<.01)$ 과 전위 공격성 $(\beta=.23, p<.01)$ 에 미치는 간접 효과는 유의하게 나타났으며, 내면화된 수치심이 전위 공격성 에 미치는 간접효과 또한 유의한 것으로 나타났다 $(\beta=.11, p<$ .01). 외생변수가 내생변수의 변량을 설명하는 정도인 다중상 관치(Squared Multiple Correlation [SMC])를 확인한 결과에서 도 내현적 자기애는 내면화된 수치심을 약 $62 \%$ 설명하였으 며, 내현적 자기애와 내면화된 수치심이 거부민감성을 설명하 는 정도는 약 $49 \%$ 였다. 또한, 내현적 자기애, 내면화된 수치심 그리고 거부민감성이 전위 공격성에 미치는 설명력은 약 $69 \%$ 로 나타났다(Table 4).

또한, 구조모형에서 각각의 간접효과에 대한 통계적 유의 성을 검증하기 위해 Sobel의 $Z$ 검증을 실시하였으며(Sobel, 1982), 그 결과 모든 경로에서의 매개효과가 유의하게 나타났 다(Table 5). 내현적 자기애가 전위 공격성에 미치는 영향에서
내면화된 수치심 $(z=2.42, p<.05)$ 과 거부민감성 $(z=3.28, p<$ .001) 모두 유의한 매개효과를 보였으며, 내현적 자기애가 거 부민감성에 미치는 영향에서 내면화된 수치심 역시 유의한 매 개효과를 보였다 $(z=8.85, p<.001)$. 또한, 마지막 매개경로인 내면화된 수치심이 전위 공격성에 미치는 영향에서 거부민감 성의 매개효과 역시 유의한 결과를 보였다 $(z=5.19, p<.001)$.

위 분석결과들을 토대로 모형 내 존재하는 각 매개경로들 의 간접효과를 종합적으로 검증한 결과, 내현적 자기애가 내 면화된 수치심을 매개하여 전위 공격성에 미치는 간접효과 $(\beta$ $=.10, p<.05)$ 는 유의하였고, 내현적 자기애가 내면화된 수치 심과 거부민감성을 순차적으로 매개하여 전위 공격성에 미치 는 간접효과 $(\beta=.09, p<.001)$ 역시 유의하게 나타났다. 또한, 내현적 자기애가 거부민감성을 매개하여 전위 공격성에 미치 는 간접효과 $(\beta=.04, p<.001)$ 도 유의미한 결과를 보였으며 위 의 매개경로들 중에서는 가장 낮은 수치를 보였다(Table 6).

\section{논의 및 결론}

본 연구는 초등학교 5,6 학년에 재학 중인 학령후기 남녀 아동

Table 4

Direct, Indirect, and Total Effects in the SEM

\begin{tabular}{|c|c|c|c|c|c|c|}
\hline & & & \multicolumn{3}{|c|}{ Bootstrapping } & \multirow[b]{2}{*}{ SMC } \\
\hline \multicolumn{3}{|c|}{ Path from latent to latent variables } & Direct effect & Indirect effect & Total effect & \\
\hline Covert narcissism & $\rightarrow$ & Internalized shame & $.79^{* * *}$ & - & $.79^{* * *}$ & .62 \\
\hline Internalized shame & $\longrightarrow$ & Rejection sensitivity & $.52^{* * *}$ & - & $.52^{* * *}$ & .49 \\
\hline Covert narcissism & $\rightarrow$ & Displaced aggression & $.57^{* *}$ & $.23^{* *}$ & $.81^{* *}$ & .69 \\
\hline
\end{tabular}

Note. $N=1,060$.

${ }^{* *} p<.01 .{ }^{* * *} p<.001$.

Table 5

Significance Verification of the Sobel Test

\begin{tabular}{lcccc}
\hline & \multicolumn{2}{c}{ Mediating path from latent to latent variables } & $z$ \\
\hline Covert narcissism & $\rightarrow$ & Internalized shame $\rightarrow \quad$ Displaced aggression & $2.42^{*}$ \\
Covert narcissism & $\rightarrow \quad$ Rejection sensitivity $\rightarrow \quad$ Displaced aggression & $3.28^{* * *}$ \\
Covert narcissism & $\rightarrow \quad$ Internalized shame $\rightarrow$ Rejection sensitivity & $8.85^{* * *}$ \\
Internalized shame & $\rightarrow \quad$ Rejection sensitivity $\rightarrow$ Displaced aggression & $5.19^{* * *}$ \\
\hline
\end{tabular}

Note. $N=1,060$.

${ }^{*} p<.05 .{ }^{* * *} p<.001$. 
Table 6

Indirect Effect of the Mediating Path

\begin{tabular}{llc}
\hline & Mediating path from latent to latent variables & Indirect effect \\
\hline Covert narcissism $\rightarrow$ Displaced aggression & $.23^{* *}$ \\
Covert narcissism $\rightarrow$ Internalized shame $\rightarrow$ Displaced aggression & $.10^{*}$ \\
Covert narcissism $\rightarrow$ Rejection sensitivity $\rightarrow$ Displaced aggression & $.04^{* * *}$ \\
Covert narcissism $\rightarrow$ Internalized shame $\rightarrow$ Rejection sensitivity $\rightarrow$ Displaced aggression & $.09^{* * *}$ \\
\hline
\end{tabular}

Note. $N=1,060$.

${ }^{*} p<.05 .{ }^{* *} p<.01 .{ }^{* * *} p<.001$.

을 대상으로 내현적 자기애가 전위 공격성에 미치는 직접적인 영향과 내면화된 수치심과 거부민감성을 통한 간접적인 영향 을 살펴보았다. 본 연구결과를 토대로 논의하면 다음과 같다.

첫째, 학령후기 아동의 내현적 자기애는 전위 공격성에 직 접적인 영향을 미쳤다. 즉, 내현적 자기애가 높은 아동일수록 전위 공격성을 더 많이 보였다. 이러한 결과는 아동 및 청소년 의 내현적 자기애가 높을수록 또래관계나 대인관계에서도 심 각한 문제를 보인다는 연구결과와 비슷한 맥락에서 일치하였 다(J.-Y. Choi \& Lee, 2014; Chun, 2015; Ju \& Lee, 2012). 내현적 자기애가 높은 아동일수록 자존감이 낮으며, 부정적인 자기개 념을 형성하고 있어 타인의 반응에 예민하고 부정적인 평가나 비판을 두려워하는 등 자신에 대해 취약한 특성을 보인다. 이 러한 특성은 취약한 자신을 보호하기 위해 회피나 억제 등의 방어기제를 사용하게 되는데, 특히 또래관계에서의 분노유발 상황이나 또래괴롭힘과 같은 좌절 상황에서 분노를 유발한 당 사자에게 직접 표출하기 보다는 갈등상황을 피하고자 분노를 억제하는 방식을 선택하게 된다. 이 때 해소되지 못한 분노는 계속해서 반추하게 됨에 따라 전혀 관계없는 상황에서 사소한 사건으로 인해 전위 공격성의 형태로 표출하게 되는 것으로 해석된다.

둘째, 학령후기 아동의 내현적 자기애는 내면화된 수치심 을 매개하여 전위 공격성에 간접적인 영향을 미쳤다. 즉, 내현 적 자기애가 강한 아동일수록 내면화된 수치심을 더 자주 경 험함에 따라 전위 공격성을 더 많이 표출함을 알 수 있었다. 이 러한 결과는 내현적 자기애가 높을수록 내면화된 수치심을 더 많이 경험하였다는 연구결과와 부분적으로 일치 하였으며 (I.-S. Choi \& Choi, 2013; Gwak \& Ha, 2010; I. S. Lee \& Choi, 2005; M. S. Lee \& Lee, 2014), 내면화된 수치심이 높을수록 높 은 전위 공격성을 보였다는 연구결과와도 부분 일치를 보였다 (J. Y. Hwang, 2014). 또한, 내현적 자기애는 내면화된 수치심을 통해 분노를 억제하는 경향을 보였다는 연구결과는 분노억제
를 통해 발생되는 전위 공격성과의 관계를 예측해주어 유사한 맥락에서 일치함을 보였다(Jung, 2010). 내현적 자기애가 강한 아동은 스스로 긍정적인 피드백을 통해 높이 평가받기를 바 라는 욕구가 강한 특성을 가진다. 그러나 생애초기단계에 이 러한 자기애적 욕구가 충족되지 못하고 좌절을 경험하면 스스 로에 대한 부정적인 자의식과 함께 내면화된 수치심을 느끼게 되는데 이는 결국 자신을 무력하고 무가치한 존재로 평가하는 취약성을 보인다. 특히 내현적 자기애가 높을수록 반추를 자 주 사용하여 부정적인 생각을 쉽게 떨치지 못함으로써 내면화 된 수치심을 더 높게 지각하게 된다. 이는 좌절을 통해 내면화 된 수치심을 경험한 상황에서 좌절과 분노를 일으킨 또래에게 직접적인 공격추동 하는 것을 더욱 어려워함에 따라 스스로 분노나 공격성을 통제하고 억제한다. 그러나 아직 해소되지 않은 분노나 공격성은 인지적 연합망 작동에 따른 반동형성으 로 반추과정을 통해 분노감을 더욱 증폭시킴으로써 주로 회피 적인 대처방식 중 하나인 전위 공격성 형태가 나타나는 것으 로 해석된다.

셋째, 학령후기 아동의 내현적 자기애 성향이 높은 아동일 수록 거부민감성이 크게 작용함에 따라 전위 공격성의 형태가 더 많이 나타났다. 이는 내현적 자기애가 높을수록 거부민감 성이 증가하여 역기능적인 분노표현방식으로 분노를 억제한 다는 선행연구결과와 일맥상통하는 결과라고 할 수 있다(M.S. Kim, 2014). 내현적 자기애가 높은 아동은 건강하지 못한 자 아상을 지니며, 특히 자기몰입적인 성향이 강하여 사회적 관 계에서 경험하는 자극이나 상호작용을 자기중심적으로 해석 함으로써 또래나 외부의 자극을 지나치게 확대해석하거나 과 민하게 반응하는 경향이 있다. 한편, 학령후기는 또래와의 상 호작용을 통해 또래집단에 소속되고자 하는 욕구가 강해지는 시기로 또래와의 사회적 관계가 더욱 중요한 시기인데, 이 시 기에 내현적 자기애가 높은 아동일수록 또래와의 관계에서 거 부당할 것이라는 거부기대에 대한 두려움과 불안은 더 커지 
며, 이로 인해 안정적인 사회적 관계를 형성하지 못한 채 오히 려 불안과 분노를 경험하게 된다. 이러한 특성은 아동으로 하 여금 경계나 방어적 기제를 사용하여 외부자극으로부터 자신 을 보호하고자 하며, 또래거부 등을 통해 또래관계에서 느낀 분노를 또래 당사자에게 직접 드러내지 못하고 억제하면서 반 추하였다가 전혀 다른 상황에서 자신보다 약한 다른 친구나 이와는 무관한 가족 및 형제자매에게 전위 공격성의 형태로 표현하게 되는 것으로 해석된다.

넷째, 학령후기 아동의 내현적 자기애는 내면화된 수치심 과 거부민감성을 매개하여 전위 공격성에 간접적인 영향을 미 쳤다. 즉, 내현적 자기애 성향이 강한 아동은 내면화된 수치심 을 더 많이 경험하게 되며, 이를 통해 거부민감성 또한 더 민 감하게 지각하고 작동함에 따라 전위 공격성이 유발되는 것이 다. 특히, 자기에 대한 부정적인 표상인 내현적 자기애가 높은 아동일수록 부정적인 자아상에 몰입하여 스스로 부적절하고 무가치한 존재로 여기는 수치심을 내면화하여 고착화시키게 된다. 이러한 부정적인 자의식 정서로 인해 또래들로부터 거 부당할 것을 두려워하고, 또래관계에서 발생하는 거부단서들 에 있어 지나치게 민감하게 반응하며 불안해하는 경향을 보인 다. 이처럼 내현적 자기애에서 비롯된 내면화된 수치심과 거 부민감성은 개인 및 대인간의 관계에서 부정적인 내적심리기 제로 작동함에 따라 또래로부터 비난이나 비판받을 상황을 우 려하게 되어 거부상황을 피하는 데에 초점을 맞추게 된다. 그 리고 이러한 고통스러운 경험으로부터 자아를 보호하기 위해 억제나 회피, 철회와 같은 방어적 기제를 사용하여 자기를 보 호하고자 하며, 자신의 분노를 유발시킨 상황이나 대상에 대 해 지속적으로 분노를 반추를 하는 성향을 보임으로써 분노를 유발시킨 당사자가 아닌 전혀 다른 상황에서 사소한 사건을 빌미로 자신보다 약한 또래나 형제자매를 향해 전위 공격성을 표출하게 되는 것으로 해석된다.

여기서 흥미로운 발견으로 그 첫 번째는 학령후기 아동의 전위 공격성을 예측하는 내적심리요인들 중에 내현적 자기애 가 가장 큰 영향을 미치고 있다는 것이다. 내현적 자기애는 내 적심리요인들 중에서도 생애초기 부모와의 상호작용을 통한 애착관계에서 가장 먼저 형성하게 되는 자기에 대한 인식이 다. 이 때 형성된 부정적인 자아상은 자신에 대해 부정적인 표 상을 형성시키게 되고, 이는 내적작동모델을 통해 생애 전반 에 걸쳐 지속적으로 영향을 미침으로써 아동의 전위 공격성을 유발시키는 가장 주된 선행요인으로 작용하게 된다는 것을 시 사한다. 두 번째 흥미로운 발견은 내현적 자기애와 전위 공격 성의 관계에서 매개경로에 따른 간접효과를 검증한 결과, 내
현적 자기애가 내면화된 수치심을 매개하여 전위 공격성에 미 치는 간접효과와 내현적 자기애가 내면화된 수치심과 거부민 감성을 순차적으로 이중 매개하여 전위 공격성에 미치는 간접 효과 간에 큰 차이를 보이지 않았다는 것이다. 이는 학령후기 아동의 전위 공격성 유발과정에서 부적절한 자아인식과 관련 된 내적요인인 내현적 자기애와 내면화된 수치심의 역할도 중 요하지만, 이것이 거부민감성을 통해 또래 및 타인에 대한 표 상마저 부정적으로 강화시킴으로써 전위 공격성을 유발하는 것으로 예측하게 된다. 결론적으로 아동 자신과 관련된 개인 심리적 요인뿐 아니라 여기서 더 나아가 대인관계에서의 내적 정서요인인 거부민감성의 증가 또한 전위 공격성을 유발시키 는 매우 중요한 증폭기제로 작동한다는 사실을 시사한다.

본 연구의 제한점과 후속 연구를 위한 제언을 하면 다음과 같다. 첫째, 본 연구는 서울, 경기도 및 충청도 소재의 4 개 초등 학교 5, 6학년 남.여 학생을 대상으로 실시하였기에 전체 아동 에 일반화하기에 한계가 있다. 특히, 각 지역별 문화 및 경제적 차이 그리고 학교 간의 특성차를 고려해볼 때 추후 연구에서 는 보다 다양하고 체계적인 표집을 통해 연구할 필요가 있다. 둘째, 본 연구에서 사용된 자료는 모두 자기보고식 척도를 사 용해 수집된 것으로, 자기보고식 측정이 지닌 한계로 인해 피 험자의 바람직한 사회적 특성 위주의 편향적인 보고나 방어기 제 등으로 인해 오류가 반영되었을 가능성이 있다. 특히, 본 연 구에서 사용된 변인들이 모두 부정적인 자아 및 자의식정서와 관련된 설문 연구인만큼 자신의 부정적인 특성을 있는 그대로 직면하여 솔직하게 답하기가 어려웠을 수 있으며, 전위 공격 성의 경우에도 실제로는 전위 공격성이 나타나지만 스스로가 전위된 공격성을 보이고 있다는 것을 잘 인지하지 못할 가능 성이 있다. 따라서 실험 관찰을 통한 연구를 진행하거나 자기 보고식 측정을 보완할 수 있는 다차원적인 자료수집방법을 고 안함으로써 측정의 객관성을 높일 필요가 있다.

이와 같은 제한점에도 불구하고 본 연구는 다음과 같은 의 의를 지닌다. 먼저, 전위 공격성과 관련된 무동기 범죄를 비롯 해 또래괴롭힘이나 따돌림과 같은 학교폭력이 발생하는 시기 가 청소년기에서 점차 저연령화 되고 있음에도 불구하고 전위 공격성에 관한 연구는 주로 성인이나 청소년을 대상으로 이루 어져 왔다. 이에 본 연구는 이른 청소년기로도 분류되는 학령 후기 아동의 전위 공격성에 관한 탐색적 연구를 진행함으로써 전위 공격성과 관련된 아동의 문제행동에 조기개입하기 위한 기초자료를 제공하였다. 또한, 지금까지의 연구들은 거의 전 위 공격성이 아동의 발달과 특성에 미치는 영향들 위주로 강 조되어온데 반해, 전위 공격성에 영향을 미치는 선행요인들 
에 관한 연구는 비교적 드문 실정이다. 이에 본 연구는 전위 공 격성과 이를 예측하는 내적심리요인인 내현적 자기애, 내면화 된 수치심, 거부민감성 간의 구조적 관계를 탐색하여 개인 및 대인간 내적심리기제의 순차적 관계를 검증하였다는데 의의 가 있다. 더 나아가 학령후기 아동의 전위 공격성 유발과정에 서 내현적 자기애와 내면화된 수치심의 역할 뿐 아니라 이러 한 부적절한 자아인식이 또래 및 타인에 대한 표상 역시 부정 적으로 강화시켜 거부민감성을 증가시킴에 따라 전위 공격성 을 예측하게 되며, 이는 아동 자신과 연관된 개인 심리적 요인 뿐 아니라 대인관계에서의 부정적인 내적정서요인인 거부민 감성의 역할 또한 매우 중요하다는 사실을 밝히게 되었다. 따 라서 본 연구에서는 아동의 전위 공격성이 개인 및 대인간의 부정적인 내적심리기제를 통해 유발되는 과정을 밝힘으로써 전위 공격성을 유발시키는 내적과정을 보다 심층적으로 이해 하여 아동상담 및 치료 시 조기중재에 사용될 수 있는 기초자 료로 유용하게 활용될 수 있을 것으로 기대한다.

\section{Notes}

This article is a part of the first author's master's thesis submitted in 2016. And this article was presented at the 2016 Annual Spring Conference of the Korean Association of Child Studies.

\section{Conflict of Interest}

No potential conflict of interest relevant to this article was reported.

\section{References}

\section{In English}

Akhtar, M. D., \& Thomson, J. A. (1982). Overview: Narcissistic personality disorder. Am J Psychiatry, 139(1), 12-20.

Allan, S., Gilbert, P., \& Goss, K. (1994). An exploration of shame measures-II: Psychopathology. Personality and Individual Differences, 17(5), 719-722.

Averill, J. R. (1983). Studies on anger and aggression: Implications for theories of emotion. American Psychologist, 38(11), 1145 -1160 .
Ayduk, O., Gyurak, A., \& Luerssen, A. (2008). Individual differences in the rejection-aggression link in the hot sauce paradigm: The case of rejection sensitivity. Journal of Experimental Social Psychology, 44, 775-782.

Bowlby, J. (1973). Attachment and Loss: Vol. 2. Separation: Anxiety and anger. New York: Basic Books.

Cheung, M. W. (2007). Comparison of approaches to constructing confidence intervals for mediating effects using structural equation models. Structural Equation Modeling: $A$ Multidisciplinary Journal, 14(2), 227-246.

Cook, D. R. (1994). Internalized shame scale: Professional manual. Menomonie, WI: Channel Press.

Cooper, A. M. (1998). Further developments in the clinical diagnosis of narcissistic personality disorder. In E. F. Ronningstam (Ed.), Disorders of narcissism: Diagnostic, clinical, and empirical implications (pp. 53-74). Washington, DC: American Psychiatric Press.

Denson, T. F. (2008). Displaced aggression in children and adolescents. In S. Y. Bhave \& S. Saini (Eds.), Angerhostility-aggression syndrome and cardiovascular diseases (pp. 43-54). New Dehli: Anamava Publications.

Dodge, K. A. (1980). Social cognition and children's aggressive behavior. Child Development, 51(1), 162-170.

Dollard, J., Miller, N. E., Doob, L. W., Mowrer, O. H., \& Sears, R. R. (1939). Frustration and aggression. New Haven: Yale University Freer.

Farrington, D. P. (2005). Childhood origins of antisocial behavior. Clinical Psychology \& Psychotherapy, 12(3), 177-190.

Feldman, S., \& Downey, G. (1994). Rejection sensitivity as a mediator of the impact of childhood exposure to family violence on adult attachment behavior. Development and Psychopathology, 6(1), 231-247.

Harder, D. W. (1990). Additional construct validity evidence for the harder personal feelings questionnaire measure of shame and guilt proneness. Psychological Reports, 67(1), 288-290.

Hu, L. T., \& Bentler, P. M. (1999). Cutoff criteria for fit indexes in covariance structure analysis: Conventional criteria versus new alternatives. Structural Equation Modeling: $A$ Multidisciplinary Journal, 6(1), 1-55.

Joireman, J. (2004). Empathy and the self-absorption paradox II: Self-rumination and self-reflection as mediators between shame, guilt, and empathy. Self and Identity, 3(3), 225-238.

Kaufman, G. (1989). The psychology of shame: Theory and treatment of shame-based syndromes. New York: Springer Publishing Company.

Kernberg, O. (1975). Borderline conditions and pathological narcissism. New York: Jason Aronson.

Kohut, H. (1971). The analysis of the self. New York: International Universities Press.

Kohut, H. (1977). The restoration of the self. New York: 
International Universities Press.

Lewis, H. B. (1971). Shame and guilt in neurosis. Psychoanalytic Review, 58(3), 419-438.

Lewis, H. B. (1987). Shame and the narcissistic personality. In L. N. Donald (Ed.), The many faces of shame (pp. 93-132). New York: Guilford Press.

Lewis, M., Alessandri, S. M., \& Sullivan, M. W. (1992). Differences in shame and pride as a function of children's gender and task difficulty. Child Development, 63(3), 630638.

Loudin, J. L., Loukas, A., \& Robinson, S. (2003). Relational aggression in college students: Examining the roles of social anxiety and empathy. Aggressive Behavior, 29(5), 430-439.

McCord, J. (1988). Parental behavior in the cycle of aggression. Psychiatry, 51(1), 14-23.

Morrison, A. P. (1983). Shame, ideal self, and narcissism. Contemporary Psychoanalysis, 19(2), 295-318.

Nagin, D., \& Tremblay, R. E. (1999). Trajectories of boys' physical aggression, opposition, and hyperactivity on the path to physically violent and nonviolent juvenile delinquency. Child Development, 70(5), 1181-1196.

Olweus, D. (1991). Bully/victim problems among schoolchildren: Basic facts and effects of a school based intervention program. The Development and Treatment of Childhood Aggression, 17, 411-448.

Piers, G., \& Singer, M. (1953). Shame and guilt. Springfield. IL: Thomas.

Rindskopf, D. (1984). Using phantom and imaginary latent variables to parameterize constraints in linear structural models. Psychometrika, 49(1), 37-47.

Sobel, M. E. (1982). Asymptotic confidence intervals for indirect effects in structural equation models. Sociological Methodology, 13, 290-312.

Steiger, J. H. (1989). EzPATH: Causal modeling: A supplementary module for SYSTAT and SYGRAPH. Evanston, IL: SYSTAT.

Tangney, J. P., \& Dearing, R. L. (2002). Shame and guilt. NY: Guilford Press.

Tangney, J. P., Wagner, P., Fletcher, C., \& Gramzow, R. (1992). Shamed into anger? The relation of shame and guilt to anger and self-reported aggression. Journal of Personality and Social Psychology, 62(4), 669-675.

Tangney, J. P., Wagner, P. E., Hill-Barlow, D., Marschall, D. E., \& Gramzow, R. (1996). Relation of shame and guilt to constructive versus destructive responses to anger across the lifespan. Journal of Personality and Social Psychology, 70(4), 797-809.

Tremblay, R. E. (2000). The development of aggressive behaviour during childhood: What have we learned in the past century. International Journal of Behavioral Development, 24(2), 129-141.
Twenge, J. M., \& Campbell, W. K. (2003). "Isn't it fun to get the respect that we're going to deserve?" Narcissism, social rejection, and aggression. Personality and Social Psychology Bulletin, 29(2), 261-272.

van der Waals, H. G. (1965). Problems of narcissism. Bulletin of the Menninger Clinic, 29(6), 293.

Walker, H. M., Severson, H. H., Feil, E. G., Stiller, B., \& Golly, A. (1998). First step to success: Intervening at the point of school entry to prevent antisocial behavior patterns. Psychology in the Schools, 35(3), 259-269.

\section{In Korean}

An, J.-H., \& Lee, S.-Y. (2013). The relations among covert narcissism, shame, anger, and reactive aggression, focusing on the role of adaptive cognitive emotion regulation strategies among middle school students. The Korean Journal of Developmental Psychology, 26(1), 61-84.

Cho, E.-Y., \& Kwak, E.-H. (2012). Anger and anger expression patterns of covert and overt narcissistic tendencies after getting failure feedback. The Korean Journal of Rehabilitation Psychology, 19(3), 583-599.

Choi, I.-S., \& Choi, H.-N. (2013). The influences of covert narcissism on social anxiety: The mediating effects of internalized shame and social self-efficacy. Korea Journal of Counseling, 14(5), 2799-2815.

Choi, J.-Y., \& Lee, Y.-S. (2014). The influences of covert narcissism, anger expression styles and empathic ability on interpersonal problems of middle school students. The Korean Journal of Rehabilitation Psychology, 21(1), 77-95.

Chun, S.-Y. (2015). Mother's dysfunctional communication and children's aggression: The mediating effects of covert narcissism. Korean Journal of Play Therapy, 18(1), 1-19.

Doh, G.-H., Choi, B.-G., \& Lee, J.-M. (2005). Relation among sociometric popularity, perceived popularity and aggression in adolescence. Family and Environment Research, 43(2), 57-67.

Gang, S.-H., \& Chung, N.-W. (2002). A study on the development and validation of the covert narcissism scale. The Korean Journal of Counseling and Psychotherapy, 14(4), 969-990.

Gwak, J. Y., \& Ha, E. H. (2010). The mediating effects of shame in the relationships between adolescents' narcissism and depression. The Korean Journal of School Psychology, 7(3), 315-331.

Ha, M.-S., \& Kim, J.-H. (2012). Development and validation of the Korean Male Gender Role Conflict Scale for Young adolescent boys (K-MGRCS-Y). Korea Journal of Counseling, 13(3), 1337-1354.

Han, S.-Y. (2007). Moral emotion and aggression among early adolescence: Focusing on guilt, shame, and empathy. 
Family and Environment Research, 45(7), 17-33.

Hong, J.-Y., \& Han, G. B. (2015). An impact of adolescent parental attachment on interpersonal problems: Mediating roles of internalized shame and rejection sensitivity. Korean Journal of Youth Studies, 22(5), 367-389.

Hong, S.-H. (2012). Psychometric properties of the Korean Children's Rejection Sensitivity Questionnaire (K-CRSQ). The Korean Journal of Elementary Counseling, 11(3), 351369.

Hong, S.-H., Gwak, P., \& Han, T.-H. (2010). Construction and validation of narcissism scale for children. The Korean Journal of School Psychology, 7(3), 333-352.

Hong, S. H., \& Lee, K. Y. (2013). The mediating effects of children's peer rejection sensitivity and hostility attribution on the relationship between peer victimization and aggression. Asian Journal of Education, 14(2), 283-315.

Hwang, J., \& Ahn, M. C. (2015). The influence of adult attachment on rejection sensitivity: The mediating effects of loneliness and shame. Journal of Human Understanding and Counseling, 36(1), 1-20.

Hwang, J. Y. (2014). Internalized shame and displaced aggression: The mediating effect of dysfunctional anger express (Master's thesis). Retrieved from http://www.riss.kr/ link?id=T13410385

Hwang, S. J., \& Park, K. H. (2014). An exploratory study on the displaced aggression in adolescents with depressive-conduct disorder tendency. Korean Journal of Health Psychology, 19(4), 1125-1147.

Jo, J.-T. (2013). Efficient bullying prevention policy. The Justice, 134(3), 141-160.

Ju, J.-Y., \& Lee, D.-G. (2012). Influence of covert narcissism on interpersonal problems in elementary school students: The sequential mediating effect of inferiority and negative automatic thoughts. Korea Journal of Counseling, 13(6), 2657-2679.

Jung, M. R. (2010). The relationship between covert narcissism and anger expression: The mediating effects of internalized shame (Unpublished master's thesis). Sungshin Women's University, Seoul, Korea.

Kang, E.-Y., \& Lee, H.-K. (2014). The relationship between rejection sensitivity and aggression: Mediating effects of cognitive emotional regulation strategy. Catholic Journal of Social Science. 30, 7-31.

Kang, M.-S., \& Lee, Y.-S. (2011). The mediating effects of cognitive emotion regulation in the relationships between covert narcissism and internalized shame. Korea Journal of Counseling, 12(5), 1545-1560.

Kim, H., \& Lee, H. (2000). Predicting variables affecting the behaviors of bullies and victims of school bullying among elementary, middle, and high school students. Korean
Journal of Educational Psychology, 15(1), 183-210.

Kim, J. (2009). Maternal parenting behaviors, children's emotional intelligence and daily hassles according to children's sex and types of aggression. Korean Journal of Child Studies, 30(6), 489-504.

Kim, M.-S. (2014). The mediating effects of rejection sensitivity and dysfunctional anger expression styles on the relationship between covert narcissism and romantic relationship dissatisfaction: Multi-group analysis by gender (Master's thesis). Retrieved from http://www.riss.kr/link?id=T13456222

Kim, P. H., \& Yun, H. M. (2014). Mediating effect of shame in the relationship of child abuse and children's depression and aggression. Journal of Korean Council for Children \& Rights, 18(4), 601-620.

Kim, S. G. (2005). A study on the effects of environmental-home, school and society and psychological variables on juvenile re-delinquency. Korean Juvenile Protection Review. 8, 165217.

Lee, H., \& Kim, E.-J. (2012). The relationship between cognitive and emotional variables and subtypes of aggression in adolescents. Korean Journal of Youth Studies, 19(1), $227-$ 250.

Lee, H. N. (2009). An exploratory study on the characteristics of the displaced aggression group (Master's thesis). Retrieved from http://www.riss.kr/link?id=T11681589

Lee, I. S., \& Choi, H. R. (2005). Assessment of shame and its relationship with maternal attachment, hypersensitive narcissism and loneliness. Korean Journal of Counseling and Psychotherapy, 17(3), 651-670.

Lee, K.-J., Hwang, S.-T., \& Jeong, D.-W. (2015). The relationships between narcissism, social rejection and delinquent behavior in adolescents. Journal of Social Science, 26(4), 4564.

Lee, M. S., \& Lee, D. H. (2014). The mediating effects of shame and self-criticism in the relation between covert narcissism and socially prescribed perfectionism. Korean Journal of Counseling and Psychotherapy, 26(4), 973-992.

Nam, K. S. (2002). The problem of differentiation between shame and guilt in related to mental health. Psychological Science, 11(1), 35-52.

Oh, H.-Y., \& Park, K. (2012). A study on the influence of covert narcissism, shame, fear of negative evaluation on social anxiety. Journal of Psychotherapy, 12(2), 77-99.

Park, J.-Y., \& Chong, Y.-S. (2008). Constructions of rejective situations for Korean children. The Korean Journal of Developmental Psychology, 21(2), 15-37.

Park, K. H., \& Seo, M. J. (2013). The relations of psychological well-being, self-esteem, somatization, depression and displaced aggression. Korean Journal of Health Psychology, 18(1), 163-181. 
Park, W. R., \& Hong, S. H. (2015). The relationships between rejection sensitivity of children and quality of friendship: The mediating effects of hostility and relational aggression. The Korean Journal of Elementary Education, 26(2), 285-302.

\section{ORCID}

Hye Eun Lim http://orcid.org/0000-0003-0305-9764

Sae-Young Han http://orcid.org/0000-0001-8207-5927

Received June 30, 2016

Revision received August 7, 2016

Accepted August 10, 2016 